\title{
NEW NATURE RESERVES IN BRITAIN
}

$\mathrm{T}$ HE Nature Conservancy has announced the establishment of a new nature reserve on the Gower Peninsula in Glamorgan, together with the extension of existing reserves at Coed Tremadoc and Bridgwater Bay.

The south coast of the Gower Peninsula in Glamorgan forms one of the most magnificent stretches of limestone cliffs in the British Isles. The steep south-facing slopes have for long been known to botanists for their exceptionally varied flora. The reservation extends over about 115 acres in the south-west corner of the peninsula and includes a short stretch of the mainland cliffs together with Worm's Head-an off-shore 'island' which is separated from the mainland only at high tide. It is situated within an area of outstanding natural beauty (National Parks and Access to the Countryside Act, 1949) and has been established under a fifty-year lease from the owners, Mr. C. P. M. MethuenCampbell and Mrs. E. G. Beynon. Negotiations are in progress for bringing further areas into the reserve.

Many sea birds breed on the cliffs and ledges of Worm's Head; while on the mainland a number of caves in the coastal cliffs contain the remains of animals and also man. It was in the Paviland caves, more than a century ago, that one of the oldest ceremonial human burials was discovered. The 'Red Lady of Paviland'-now known to have been a man -had been stained in red ochre (the symbol of blood and life). Animal bones belonging to the Pleistocene age recovered from some of these caves include the remains of horse, bear and ox, together with mammoth, woolly rhinoceros, elk, wolf and reindeer.

The reserve is of interest to geologists because it reveals a detailed rock succession in Lower Carboniferous sediments of both Visean and Tournasian age which is not to be seen elsewhere in South Wales. These limestone cliffs are also of great botanical interest in that they bear a rich flora characteristic of limestone; they also support a number of rare plant species which form part of a relict flora to-day found only on massive outcrops of Carboniferous Limestone in a few places on the western shore of Britain.

Access to the reserve is unrestricted, but those wishing to collect specimens of animals or plants, or to carry out research on the reserve, should apply for permission to Mr. P. Walters Davies, South Wales Regional Officer, The Nature Conservancy, c/o Department of Zoology, University of Swansea, Singleton Park, Swansea.

A further small area of 8 acres, which has now also been added to the Coed Tremadoc reserve (Nature, 180,$78 ; 1957$ ), comprises part of the more westerly cliffs behind the village of Tremadoc known as Craig y Dref and Craig y Castell.

These cliffs are mainly composed of a massive intrusion of dolerite, flanked by a more acidic igneous rock. The crest of the cliff bears an extensive and interesting woodland of dwarf oak. As at Craig Pant Ifan, the eliffs are vegetated, though open faces do exist, and on these there are a number of fine rockclimbs. The soil of the apparently untouched ledges and gullies is of great interest as it has a very considerable depth of accumulated humus of a kind not to be found elsewhere within the more disturbed woodlands of Wales. The humus is very unstable, and trampling on the ledges, gullies and fairly steep rock faces where it accumulates sets it moving very easily. The Conservancy, while permitting rockclimbing, wish to direct this activity to the leastvegetated part of the cliffs so as to keep intact the essentially native vegetation and soils of some of the ledges and gullies. Here it has the help and cooperation of the owner, Capt. Livingstone-Learmonth, the tenants of Pant Ifan, the Birmingham Cave and Crag Club and the Climbers Club in the reconeiliation of the interests of nature conservation and rockclimbing, and to this end the Birmingham Cave and Crag Club and the Nature Conservancy have devised a "Climbing Code".

Access to the reserve is by permit only, and applications should be addressed to the Conservation Officer, The Nature Conservancy, Y Fron, The Crescent, Upper Bangor, Bangor. Permits for rockclimbing can be obtained from the honorary secretary of the Birmingham Cave and Crag Club, Mr. D. Snell, 29 Beacon Road, Wylde Green, Sutton Coldfield. It is requested that applications for such permits should be made by the secretaries of mountaineering clubs on behalf of their members, but individual climbers may obtain permits locally from Capt. S. T. A. Livingstone-Learmonth, of Tan-yr-Allt, Tremadoc, or from the Nature Conservancy's warden, Mr. Evan Roberts, Gwynant, Capel Curig.

The Bridgwater Bay nature reserve (covering some 6,000 acres) was established in 1954 under an agreement with the Somerset River Board. When approval was given in June 1957 for the erection of a nuclear power station adjoining the reserve at Hinkley Point, approximately 14 acres had to be excluded from the reserve to meet the requirements of the Central Electricity Generating Board. The recent declaration excludes this area, but brings into the reserve Fenning Island, which has been purchased by the Conservancy from the owner, Mr. R. S. Gliddon.

Fenning Island, which was shown on the Ordnance Survey map of 1886 as separated from the mainland by a broad tidal creek, had been joined to the mainland by the time of the 1902 revision. The present supply of shingle to the ridge fronting Fenning Island and the growth of the large creek which now almost severs it from the mainland suggest that the separation may be re-enacted. The area is covered with a close-grazed sward of common saltmarsh grass, Puccinellia maritima, and is subject to occasional tidal flooding. For some time the Conservancy has maintained on Fenning Island, with Mr. Gliddon's permission, experimental plots in connexion with the research work of its coastal study section. While it is not intended to include in the by-laws any restriction of access over Fenning Island, there is a grazing tenancy over the land, which means that it must be treated as normal agricultural land. 